\title{
ENTREPRENEUR
}

Jurnal Bisnis Manajemen Dan Kewirausahaan

Program Studi Manajemen Fakultas Ekonomika dan Bisnis Universitas Majalengka

Published every January and July e-ISSN : (Proses), p-ISSN: 2723-1941

Available online http://ejournal.unma.ac.id/index.php/entrepreneur

\section{Usulan Strategi Pemasaran Berdasarkan Costumer Retention Dalam Menghadapi Persaingan Kedai Kopi di Daerah Sekitar Kota Sumedang Studi Kasus: Sawala Space \& Café}

\author{
Aldirafi Gani ${ }^{1}$, Cecep Safa'atul Barkah ${ }^{2}$, Tetti Herawaty ${ }^{3}$, Lina Auliana ${ }^{4}$. \\ Ilmu Administrasi Bisnis, Fakultas Ilmu Sosial dan Ilmu Politik, Universitas Padjadjaran. \\ Aldirafi19001@mail.unpad.ac.id
}

\begin{abstract}
.
Kebutuhan konsumsi kopi terjadi peningkatan yang ditandai dengan adanya perbahan gaya hidup pelanggan. Akibat dari peningkatan jumlah konsumsi tersebut banyak orang tertarik untuk membuka bisnis kedai kopi. Banyak kedai kopi menawarkan berbagai macam produk untuk menarik perhatian pelanggan. Penelitian ini, dilakukan untuk mengetahui bagaimana retention pelanggan serta bagaimana cara untuk memberikan usulan strategi pemasaran. Penelitian ini dilakukan di Sawala Space \& Cofe. Untuk strateginya sendiri memuat beberapa aspek yang dibahas yaitu seperti pendekatan analisis internal perusahaan, kerangka VRIO, Sustainable Competitive Advantage(SCA) dan analisis TOWS. Hasil penelitian ini menghasilkan usulan strategi pemasaran yang bersifat berkelanjutan dan menguntungkan kedai kopi Sawala Space \& Cofe.
\end{abstract}

Keywords:

Strategy marketing; Sustainable Competitive Advantage (SCA);Costumer Retention

\section{PENDAHULUAN}

Pada saat sekarang ini, persaingan usaha dirasakan semakin ketat dan semakin kompleks. Banyaknya produk menyebabkan konsumen cenderung beralih dari satu produk ke produk lainnya. Persaingan terjadi pada setiap bidang bisnis tak terkecuali bisnis Coffee Shop.

Sesuai yang tertulis dalam Kamus Besar Bahasa Indonesia (1998, "kedai kopi (coffee shop) adalah suatu tempat (kedai) yang menyajikan olahan kopi espreso dan kudapan kecil". Sehingga berdasarkan definisi tersebut, Sawala Space \& Cofe dikategorikan sebagai bisnis Coffee Shop

Berdasarkan data BPS, tingkat konsumsi Kopi di Indonesia meningkat dari tahun 2015 sampai 2019 terjadi peningkatan sebesar $1,79 \mathrm{~kg} / \mathrm{kapita} / \mathrm{tahun}$. Ini menjadi pertanda bahwa konsumsi kopi tidak lagi sebagai minuman yang digunakan hanya untuk dapat bergadang dimalam hari saja melainkan terjadi perubahan dimana orang orang menganggap kopi sebagai lifestyle dimana kopi menjadi kebutuhan hidup sehingga membuka banyak peluang bagi banyak pihak khususnya kedai kopi untuk membuat bisnisnya menjadi semakin besar.

Persaingan saat ini terjadi sangat ketat. Tidak terjadi di kota besar saja, dunia usaha saat ini berkembang bertahap ke daerah daerah kecil, seperti halnya di Kab. Sumedang yang merupakan daerah yang tidak tergolong 


\section{ENTREPRENEUR}

\section{Jurnal Bisnis Manajemen Dan Kewirausahaan}

\section{Program Studi Manajemen Fakultas Ekonomika dan Bisnis Universitas Majalengka}

Published every January and July e-ISSN : (Proses), p-ISSN: 2723-1941

Available online http://ejournal.unma.ac.id/index.php/entrepreneur

besar di Indonesia, bahkan aktivitas penduduknya juga tidak terlalu sibuk dikarenakan terjadi pandemi yang mengharuskan orang bekerja dari rumah demi keselamatan diri. Hal ini juga menyebabkan perilaku konsumen berubah dari yang biasanya membeli dan menyantapnya di tempat sekarang membeli dan membawa pulang(take away). Apalagi dengan ada aturan PSBB, PPKM, PPKM-mikro ini menuntut pelaku bisnis bahkan konsumen untuk melakukan perubahan.

Ditengah maraknya persaingain ini terdapat beberapa kedai kopi yang dapat bertahan, salah satunya yaitu Sawala Space \& Cofe. Kedai kopi ini terletak di Jl. R.A. Kartini No.28, Regol Wetan, Kec. Sumedang Sel., Kabupaten Sumedang, Jawa Barat 45311. Belakangan ini terdapat kedai kopi lainnya yang menjadi perhatian kaum muda yaitu Café Nyoesdoel(nyusu dulu), Rootspace \& Café Poma.

Hal ini mengharuskan pimpinan dan pekerja di kedai kopi Sawala harus memutar otak agar dapat bersaing sehingga pelanggan tidak berpaling ke lain pihak.

Dalam mempertahankan pelanggan, perusahaan berusaha mengejar kepuasan pelanggan untuk menciptakan loyalitas pelanggan. "Loyalitas pelanggan tidak cukup untuk dapat menjamin kelangsungan hidup suatu perusahaan. Maka diperlukan adanya tindakan perusahaan program kerja yang dapat menunjukkan bahwa pelanggan loyal terhadap perusahaan customer retention" (Battle, 2004). Menurut Getts dan Thomas (2001), menyatakan bahwa retensi pelanggan terjadi ketika pelanggan berulang kali membeli produk atau jasa, fenomena ini disebut sebagai retensi pelanggan melebihi suatu periode waktu. "Kepuasan pelanggan menjadikan hal yang sangat penting untuk menentukan berhasil atau tidaknya suatu perusahaan." (Kau dan Elizabeth, 2006). Memastikan bahwa pelanggan telah puas secara berkesinambungan merupakan hal yang sulti untuk dilakukan.

Cara yang dapat dilakukan untuk (mempertahankan konsumen) mengukur daya tarik pelanggan adalah dengan mengukur tingkat retensi (retention rate).

Berdasarkan pembahasan tersebut, penulis berusaha melakukan penelitian dimana dengan menggunakan studi costumer retention diharapkan dapat memberikan pilihan strategi bisnis yang baik. Karena strategi pemasaran adalah kunci untuk mencapai organisasi yang lebih efektif dari pada pesaing dalam memuaskan kebutuhan pelanggan (Kotler,1997).

Dalam penelitian ini akan mencari tingkat retention rate lini produk kopi di Sawala Space \& Cofe dan apakah retention rate tersebut sudah bagus atau harus ditingkatkan. Kemudian melakukan serangkaian analisis untuk mencari usulan pemasaran yang ditunjang dengan analisis tersebut sehingga akan memberikan benefit dan impact bagi perusahaan dan pelanggan.

\subsection{Perhitungan Retention Rate Lini Produk Kopi di Sawala Space \& Café}

Berikut ini adalah hasil perhitungan retention rate pada lini produk Kopi, sebagai berikut:

Tabel 1. Perhitungan Retention Rate

Pada Produk Kopi di Sawala Space \&Caffe

Periode 12 Maret - 13 Mei 2021 


\section{ENTREPRENEUR}

Jurnal Bisnis Manajemen Dan Kewirausahaan

Program Studi Manajemen Fakultas Ekonomika dan Bisnis Universitas Majalengka Published every January and July e-ISSN : (Proses), p-ISSN: 2723-1941 Available online http://ejournal.unma.ac.id/index.php/entrepreneur

\begin{tabular}{|c|c|c|c|c|}
\hline $\begin{array}{l}\text { Nama } \\
\text { Produk }\end{array}$ & $\begin{array}{l}\text { Periode } \\
\text { Awal(CS) }\end{array}$ & $\begin{array}{l}\text { Pembeli } \\
\text { baru(CN) } \\
\text { selama periode }\end{array}$ & $\begin{array}{l}\text { Periode } \\
\text { akhir(CE) }\end{array}$ & $\begin{array}{l}\text { Retention } \\
\text { Rate\% }\end{array}$ \\
\hline Americano & 21 & 16 & 22 & 28,57142857 \\
\hline $\begin{array}{l}\text { Vietnam } \\
\text { Drip }\end{array}$ & 16 & 14 & 15 & 6,25 \\
\hline Espresso & 17 & 10 & 18 & 47,05882353 \\
\hline $\begin{array}{ll}\text { Ini } & \text { Mah } \\
\text { Kopi } & \\
\end{array}$ & 21 & 7 & 12 & 23,80952381 \\
\hline $\begin{array}{l}\text { Chappucino } \\
\text { hot }\end{array}$ & 13 & 11 & 12 & 7,692307692 \\
\hline $\begin{array}{l}\text { Chappucino } \\
\text { ice }\end{array}$ & 16 & 18 & 21 & 18,75 \\
\hline $\begin{array}{ll}\text { Es } & \text { Kopi } \\
\text { Gula } & \\
\text { Aren } & \\
\end{array}$ & 6 & 5 & 8 & 50 \\
\hline $\begin{array}{l}\text { Hot Coffe } \\
\text { Latte }\end{array}$ & 15 & 17 & 19 & 13,33333333 \\
\hline $\begin{array}{l}\text { Ice Coffe } \\
\text { Original }\end{array}$ & 10 & 8 & 11 & 30 \\
\hline $\begin{array}{l}\text { Ice Coffe } \\
\text { Vanilla }\end{array}$ & 15 & 16 & 25 & 60 \\
\hline $\begin{array}{l}\text { Moccacino } \\
\text { Hot }\end{array}$ & 10 & 12 & 16 & 40 \\
\hline $\begin{array}{l}\text { Moccacino } \\
\text { Ice }\end{array}$ & 20 & 18 & 19 & 5 \\
\hline $\begin{array}{l}\text { Japanese } \\
\text { Coffe }\end{array}$ & 13 & 12 & 16 & 30,76923077 \\
\hline \multicolumn{4}{|c|}{ Rata - rata Retention Rate\% } & 27,78728059 \\
\hline
\end{tabular}

Berdasarkan tabel tersebut diketahui Sawala Space \& Cofe memiliki lini produk khusus untuk kopi dengan berbagai macam varian jenis dan rasa. Masing-masing memiliki tingkat retention rate produk yang berbeda-beda.

Hal tersebut dipengaruhi oleh berbagai faktor. Misalnya pada produk ice coffe Vanila, dengan retention rate sebesar $60 \%$ dicapai karena dengan semakin tingginya jumlah konsumen di periode akhir (CE) dan semakin rendahnya konsumen baru $(\mathrm{CN})$ kemudian semakin rendahnya consumen awal (CS). Ini mengindikasi adanya peningkatan pembelian berulang (repeat buying). Lalu juga ada indikasi terjadi peningkatan penjualan. Sedangkan apabila kita melihat pada produk Moccacino Ice, yang nilai retention rate itu sendiri sebesar $5 \%$ tetapi diikuti dengan $\mathrm{CN}$ yang tinggi ini mengindentifikasikan bahwa produk tersebut masih berada pada fase pertumbuhan (growing). Lalu pada CE terjadi fase kedewasaan(maturity) karena produk 


\section{ENTREPRENEUR}

\section{Jurnal Bisnis Manajemen Dan Kewirausahaan}

\section{Program Studi Manajemen Fakultas Ekonomika dan Bisnis Universitas Majalengka}

Published every January and July e-ISSN : (Proses), p-ISSN: 2723-1941

Available online http://ejournal.unma.ac.id/index.php/entrepreneur

tersebut mampu mempertahankan penjualannya. Sehingga ini bukan berarti produk tersebut tidak bagus, melainkan produk tersebut bukan produk yang cocok untuk dijadikan acuan retention rate.

Pertanyaannya apakah nilai 27,787 tersebut merupakan nilai yang baik bagi perusahaan? dilansir dari Localytics(2018), bahwa retention rate dikategorikan dalam industry retail memiliki range $36-44 \%$. Jadi jika Sawala Space \& Cofe saat ini berada pada retention rate sebesar 27,787 maka dapat dikatakan bahwa perusahan berada di bawah rata rata retention rate industri ritel sehingga perlu dilakukan usulan strategi pemasaran agar meningkatan retention rate tersebut.

\section{KERANGKA TEORITIS DAN HIPOTESIS}

\subsection{Costumer Retention}

Menurut Anderson \& Mittal, "Customer retention merupakan penghubung antara loyalitas pelanggan dan profitabilitas perusahaan". Customer retention merupakan bentuk loyalitas konsumen yang ditandai dengan tingginya frekuensi pembelian produk (behavioural loyalty). "Loyalitas mengacu pada sikap (attitudinal loyalty) dengan kriteria pengukuran sikap, keyakinan, perasaan dan kehendak untuk melakukan pembelian" (Buttle, 2014). Menururt Ennew \& Blinks (2016) "bahwa loyalitas dan retensi merupakan hal yang berbeda. Loyalitas adalah attitudinal construct atau sikap pelanggan terhadap perusahaan sedangkan retensi adalah behavioral construct atau berhubungan dengan perilaku pelanggan terhadap perusahaan".

$$
\text { Penulis menyimpulkan bahwa }
$$
costumer retention merupakan kegiatan pemasaran dimana bertujuan untuk mempertahankan pelanggan dengan melakukan pengembangan produk sehingga menyebabkan perilaku pembelian berulang bagi konsumen.

\subsection{Retention Rate}

Menurut Farris P. W., et all. "Bahwa pendefinisian retention rate merupakan suatu hal yang jarang digunakan dalam dunia pemasaran oleh sebab itu tidak disarankan untuk mengandalkan nama metrics ini sebagai acuan indikator sempurna tentang cara perhitungannya". Dalam buku tersebut mendefinisikan retention rate sebagai tingkat pengulangan (repeat rate) dan pembelian kembali (repurchase rate). Repeat rate didefinisikan sebagai persentase pelanggan merek pada periode waktu tertentu yang juga merupakan pelanggan merek periode berikutnya sedangkan repurchase rate didefinisikan sebagai persentase pelanggan merek yang membeli kembali merek tersebut pada kesempatan pembelian berikutnya. Retention rate, memiliki periode pengukuran semakin pendek waktu periode yang digunakan, semakin rendah tingkat pengulangannya. Begitu pula sebaliknya.

\subsection{Perhitungan Retention Rate}

Retention rate dapat dihitung melalui rumus berikut ini:

$$
\left(\frac{(C E-C N)}{C S}\right) x 100
$$

Sumber:productplan.com/glossary/retention-rate/ $\mathrm{CE}=$ Jumlah konsumen di akhir periode $\mathrm{CN}=$ Jumlah konsumen baru selama periode $\mathrm{CS}=$ Jumlah konsumen di awal periode

\subsection{Internal Resources Based}

Internal based resource juga dikenal sebagai resource based view of the firm. Barney dalam Son (2011) menegaskan bahwa internal based resource ini adalah kerangka untuk meneliti kekuatan dan kelemahan internal perusahaan.

Internal resources based merupakan sebuah analisis terhadap sumber daya internal perusahaan. Internal resources based menekankan kelebihan dan kekurangan internal perusahaan dengan cara memperhatikan detail keunikan sumber daya 


\section{ENTREPRENEUR}

\section{Jurnal Bisnis Manajemen Dan Kewirausahaan}

Program Studi Manajemen Fakultas Ekonomika dan Bisnis Universitas Majalengka

Published every January and July e-ISSN : (Proses), p-ISSN: 2723-1941

Available online http://ejournal.unma.ac.id/index.php/entrepreneur

internal perusahaan. Setelah itu data tersebut digunakan untuk memenangkan persaingan antar perusahaan.

Dengan mengetahui kekuatan dan kekurangan internal perusahaan ini, membuat retention rate perusahaan menjadi matang untuk dilakukan.

\subsection{Analisis VRIO}

"Analisis VRIO (Valuable, Rare, Inimitable, Organization) digunakan untuk mengehui sumber daya yang nyata (tangible) dan tidak nyata (intangible) dalam suatu perusahaan untuk mengetahui perusahaan tersebut memiliki keunggulan bersaing berkelanjutan atau tidak". Barney \& Hesterly (2015) dalam Saragih mengutarakan dengan jelas, VRIO digunakan sebagai analisis internal perusahaan. Dalam pelaksanaannya terdapat empat pertanyaan yaitu Value (nilai), Rarity (kelangkaan), Imitablility (kemungkinan peniruan) dan Organization (organisasi).

a. Value (nilai), menjelaskan tentang respon sumber daya perusahaan terhadap peluang ataupun ancaman yang ada di lingkungan baik internal maupun eksternal.

b. Rarity (kelangkaan), menjelaskan tentang ukuran keuntungan rata-rata perusahaan di industri terkait yang memiliki pesaing dengan sumber daya yang sama.

c. Imitability (kemungkinan peniruan), dapat dilihat dengan memperhatikan cost disadvantage atau kerugiaan biaya perusahaan.

d. Terakhir Organization, perusahaan harus memiliki kemampuan untuk melakukan pengaturan dalam manajemen, proses kerja, kebijakan perusahaan, struktur organisasi, sehingga tercipta budaya organisasi yang sepenuhnya menyadari potensi yang dimiliki perusahaan untuk dapat mencapai keunggulan bersaing yang berkesinambungan.

\subsection{Analisis TOWS Matriks}

Analisis TOWS matriks ini berbeda dengan SWOT. Dimana dalam SWOT lebih menekankan analisis internal perusahaan tergabung dalam Strengths dan Weaknesses, lalu kemudian melakukan analisis ekternal berupa Opportunities dan Threats. Sedangkan dalam TOWS, perusahaan dituntut untuk melakukan pengamatan,, identifikasi hingga investigasi segala pilihan- pilihan strategi yang akan dilakukan kepada pihak eksternal. Dimana ini dilakukan untuk mengenali segala kemungkinan sehingga perusahaan dapat mengontrol dan mengendalikan segala kemungkinan yang hadir dari luar baik itu sifatnya ancaman ataupun peluang. TOWS memiliki empat strategi yang biasa digunakan, seperti berikut:

a. Strenght/Opportunity(SO):

menekankan bagaimaan caranya agar kekuatan perusahaan yang dimiliki dapat mengeksploitasi peluang.

b. Weakness/Opportunity (WO): bagaimana cara perusahaan mengatasi kelemahan sehingga dapat mengambil keuntungan dari peluang yang ada.

c. Strenght/Threat(ST): Bagaimana cara perusahaan untuk mengeksploitasi kekuatan sehingga dapat mengatasi ancaman.

d. Weakness/Threat (WT): Bagaimaan cara agar dapat mengurangi kelemahan untuk menghindari ancaman.

\subsection{Analisis SCA (Sustainable Competitive Advantage)}

Setiap perusahaan menginginkan agar keunggulan perusahaan dapat dipertahankan dan dikembangkan salah satunya dengan melalui analisis SCA (Sustainable 


\section{ENTREPRENEUR}

\section{Jurnal Bisnis Manajemen Dan Kewirausahaan}

Program Studi Manajemen Fakultas Ekonomika dan Bisnis Universitas Majalengka

Published every January and July e-ISSN : (Proses), p-ISSN: 2723-1941

Available online http://ejournal.unma.ac.id/index.php/entrepreneur

Competitive Advantage) atau juga disebut

Keunggulan kompetitif berkelanjutan.

Analisis SCA dilakukan oleh perusahaan untuk mendapatkan kriteria atau sumber daya suatu perusahaan untuk dianalisis dan dibandingkan dengan perusahaan lainnya dengan perusahaan atau pasar yang sama dimana perusahaan yang dianalisis tersebut telah memiliki keunggulan bersaing dan kinerja sumber daya yang lebih tinggi dibanding perusahaan lain.

\section{METODOLOGI PENELITIAN}

\subsection{Jenis dan Lokasi Penelitian}

Metode penelitian yang digunakan yaitu metode penelitian kualitatif desktiptif berupa pendekatan studi kasus (case study) dimana memusatkan diri secara intensif pada satu obyek tertentu yang mempelajarinya sebagai suatu kasus. Informasi studi kasus bisa diperoleh dari berbagai sumber. Informasi studi kasus bisa diperoleh tidak saja dari kasus yang diteliti, namun, pula bisa diperoleh dari seluruh pihak yang mengenali serta memahami kasus tersebut dengan baik. "Data dalam studi kasus bisa diperoleh dari bermacam sumber tetapi terbatas dalam kasus yang hendak diteliti". (Nawawi 2003:1-2).

Lokasi penelitian di Sawala Space \& Café yang berada di Kabupaten Sumedang, Provinsi Jawa Barat.

\subsection{Sumber Data}

Untuk sumber data yang dikumpulkan dalam penelitian ini merupakan berasal dari data primer maupun sekunder.

\section{a. Sumber Data Primer}

Sesuai pendapat Danang Sunyoto, "Data primer merupakan data yang masih oroiginal yang seharusnya diperoleh peneliti untuk menjawab permasalahan peneltian".

Dalam melengkapi data primer, penulis melakukan metode wawancara secara mendalam kepada narasumber terkait. Salah satunya kepada manager operasional di Sawala Space \& Café.

\section{b. Sumber Data Sekunder}

Data sekunder diperoleh melalui oranga tau dokumen yang berfungsi sebagai pelengkap data primer.

Untuk melengkapi data sekunder, penulis menggunakan pencarian data melalui laporan historis atau arsip perusahaan dengan mengakses dokumen terkait transaksi pembelian antara costumer dengan Sawala Space \& Café.

\subsection{Instrumen Penelitian}

Instrumen utama dalam penelitian ini adalah penulis sendiri. Penulis menggunakan media Google Form, Zoom Meeting, dan pedoman wawancara dalam mendukung proses pengumpulan data.

\subsection{Teknik Pengumpulan Data}

Menurut Riduwan (2010:51), "teknik pengumpulan merupakan cara yang digunakan oleh para peneliti untuk mengumpulkan data". a. Wawancara

Wawancara digunakan sebagai

Cara untuk menggali permasalahan yang harus diteliti secara mendalam kepada responden.

Melalui wawancara peneliti melakukan tanya jawab kepada pemilik perusahaan secara tatap muka maupun melalui telepon untuk mengetahui lebih dalam mengenai permasalahan yang berkaitan dengan penelitian.

b. Studi Dokumen

Dokumentasi merupakan jejak peristiwa atau catatatan peristiwa yang sudah dilakukan perusahaan yang berkaitan dengan penelitian". Berupa tulisan, gambar, atau karya-karya. Dokumen dalam penelitian ini berupa bukti transaksi dari penjualan Sawala Space \& Cofe.

\subsection{Analisis Data}

"Analisa data yang dilakukan dalam peneltian kualitatif merupakan proses induktif dalam mengolah data menjadi beberapa katagori dan mengindentifikasi pola-pola 


\section{ENTREPRENEUR}

\section{Jurnal Bisnis Manajemen Dan Kewirausahaan}

Program Studi Manajemen Fakultas Ekonomika dan Bisnis Universitas Majalengka Published every January and July e-ISSN : (Proses), p-ISSN: 2723-1941

Available online http://ejournal.unma.ac.id/index.php/entrepreneur

(hubungan) dari katagori-katagori tersebut". (Mc.Milla\&Schumacher, 2001).

Analisis data yang dilakukan yaitu menggunakan matriks Subtainable Competitive Advantage (SCA), VRIN dan juga TOWS.

\section{HASIL DAN PEMBAHASAN}

\subsection{Analisis Internal Perusahaan}

Data yang diambil dari analisis internal perusahaan terdiri dari hasil wawancara secara langsung bersama Kang Jajang Badru sebagai manajer operasional untuk menentukan resources, capabilities dan competencies di Sawala Space \& Café.

Analisis internal perusahaan dapat dilihat pada tabel berikut:

Tabel 2. Analisis Internal Perusahaan

\begin{tabular}{|c|c|c|c|}
\hline No. & Resources & Capabilities & Competencies \\
\hline & A. Tangible & & \\
\hline \multirow[t]{3}{*}{1} & Gedung & $\begin{array}{l}\text { Bisa menampung } 100 \\
\text { orang }\end{array}$ & $\begin{array}{l}\text { Daya tampung lebih } \\
\text { dari pesaing lainnya. }\end{array}$ \\
\hline & & 15 Tahun & $\begin{array}{c}\text { Sama dengan } \\
\text { kompetitor }\end{array}$ \\
\hline & & 1 lantai & $\begin{array}{c}\text { Kompetitor lebih } \\
\text { unggul }\end{array}$ \\
\hline \multirow[t]{3}{*}{2} & Tempat parkir & Menampung 3 mobil & $\begin{array}{c}\text { Kompetitor lebih } \\
\text { unggul }\end{array}$ \\
\hline & & $\begin{array}{c}\text { Menampung } 30 \\
\text { mobil }\end{array}$ & $\begin{array}{c}\text { Kompetitor lebih } \\
\text { unggul }\end{array}$ \\
\hline & & $\begin{array}{c}\text { Usia ekonomis } 5 \\
\text { tahun }\end{array}$ & $\begin{array}{c}\text { Kompetitor lebih } \\
\text { unggul }\end{array}$ \\
\hline \multirow[t]{3}{*}{3.} & Kursi meja & 25 meja & $\begin{array}{c}\text { Kompetitor lebih } \\
\text { unggul }\end{array}$ \\
\hline & & 66 kursi & $\begin{array}{c}\text { Daya tamping } \\
\text { melebihi pesaing } \\
\text { serta tempat kopi } \\
\text { lainnya }\end{array}$ \\
\hline & & $\begin{array}{c}\text { Umur ekonomis } 4 \\
\text { tahun }\end{array}$ & $\begin{array}{c}\text { Kompetitor lebih } \\
\text { unggul }\end{array}$ \\
\hline \multirow[t]{2}{*}{4} & Wifi & $20 \& 50 \mathrm{Mbps}$ & $\begin{array}{c}\text { Kompetitor lebih } \\
\text { unggul }\end{array}$ \\
\hline & & 3 router & $\begin{array}{c}\text { Jumlah kepemilikan } \\
\text { lebih dari pesaing } \\
\text { lainnya }\end{array}$ \\
\hline
\end{tabular}




\begin{tabular}{|c|c|c|c|}
\hline \multicolumn{4}{|c|}{$\begin{array}{c}\text { ENTREPRENEUR } \\
\text { Jurnal Bisnis Manajemen Dan Kewirausahaan } \\
\text { Program Studi Manajemen Fakultas Ekonomika dan Bisnis Universitas Majalengka } \\
\text { Published every January and July e-ISSN : (Proses), p-ISSN: } 2723-1941 \\
\text { Available online http://ejournal.unma.ac.id/index.php/entrepreneur }\end{array}$} \\
\hline 5 & Mesin kopi & 17 buah & $\begin{array}{c}\text { Kompetitor lebih } \\
\text { unggul }\end{array}$ \\
\hline 6 & Peralatan makan & 93 set & $\begin{array}{c}\text { Jumlah stok yang } \\
\text { lebih banyak } \\
\text { dibanding pesaing } \\
\text { lainnya }\end{array}$ \\
\hline \multirow[t]{2}{*}{7} & \multirow[t]{2}{*}{ Peralatan dapur } & $31 \mathrm{set}$ & $\begin{array}{l}\text { Jumlah barang yang } \\
\text { dimiliki lebih dari } \\
\text { yang dimiliki } \\
\text { pesaing. }\end{array}$ \\
\hline & & $\begin{array}{c}30 \text { menu dalam satu } \\
\text { hari }\end{array}$ & $\begin{array}{c}\text { Kompetitor lebih } \\
\text { unggul }\end{array}$ \\
\hline \multirow[t]{3}{*}{8} & \multirow[t]{3}{*}{ Fasilitas } & $\mathrm{AC}$ ada 2 & $\begin{array}{l}\text { Kompetitor lebih } \\
\text { unggul }\end{array}$ \\
\hline & & Kipas angina ada 1 & $\begin{array}{c}\text { Kompetitor lebih } \\
\text { unggul }\end{array}$ \\
\hline & & Kulkas 5 & $\begin{array}{l}\text { Jumlah stok lebih } \\
\text { menandakan } \\
\text { kelebihan dibanding } \\
\text { pesaing lain }\end{array}$ \\
\hline \multirow[t]{4}{*}{9} & \multirow[t]{4}{*}{ Prasarana } & $\begin{array}{c}\text { Mushola kapasitas } 5 \\
\text { orang }\end{array}$ & $\begin{array}{c}\text { Sama dengan } \\
\text { kompetitor }\end{array}$ \\
\hline & & $\begin{array}{c}\text { Perpustakaan } 15 \\
\text { orang }\end{array}$ & $\begin{array}{l}\text { Kapasitas serta } \\
\text { fasilitas lebih dari } \\
\text { yang dimiliki } \\
\text { pesaing. }\end{array}$ \\
\hline & & Toilet 1 & $\begin{array}{c}\text { Kompetitor lebih } \\
\text { unggul }\end{array}$ \\
\hline & & $\begin{array}{c}\text { Room meeting } 20 \\
\text { orang }\end{array}$ & $\begin{array}{c}\text { Fasilitas tidak } \\
\text { dimiliki pesaing }\end{array}$ \\
\hline \multirow[t]{2}{*}{10} & \multirow[t]{2}{*}{ Mesin kasir } & 1 & $\begin{array}{l}\text { Sama dengan } \\
\text { competitor }\end{array}$ \\
\hline & & $\begin{array}{c}\text { Usia ekonomis } 5 \\
\text { tahun }\end{array}$ & $\begin{array}{c}\text { Sama dengan } \\
\text { kompetitor }\end{array}$ \\
\hline 11 & Hiburan & Live music $\mathrm{x}$ sebulan & $\begin{array}{c}\text { Kompetitor lebih } \\
\text { unggul }\end{array}$ \\
\hline \multirow[t]{2}{*}{12} & Lokasi & Strategis & $\begin{array}{l}\text { Di tengah kota (lebih } \\
\text { strategi) }\end{array}$ \\
\hline & B. Intangible & & \\
\hline 1. & Merek & Memiliki 2 merek & $\begin{array}{l}2 \text { Merek sudah cukup } \\
\text { dikenal pelanggan }\end{array}$ \\
\hline
\end{tabular}




\begin{tabular}{|c|c|c|c|}
\hline & \multicolumn{3}{|c|}{$\begin{array}{c}\text { ENTREPRENEUR } \\
\text { Jurnal Bisnis Manajemen Dan Kewirausahaan } \\
\text { Program Studi Manajemen Fakultas Ekonomika dan Bisnis Universitas Majalengka } \\
\text { Published every January and July e-ISSN : (Proses), p-ISSN: 2723-1941 } \\
\text { Available online http://ejournal.unma.ac.id/index.php/entrepreneur }\end{array}$} \\
\hline & & & $\begin{array}{l}\text { (ini mah kopi dan } \\
\text { juragan jamu) }\end{array}$ \\
\hline 2. & Relasi & $\begin{array}{c}\text { Memiliki relasi } \\
\text { dengan komunitas } \\
\text { dan vendor }\end{array}$ & $\begin{array}{l}\text { Memiliki relasi yang } \\
\text { lebih banyak } \\
\text { sehingga lebih unggul }\end{array}$ \\
\hline \multirow[t]{2}{*}{3.} & \multirow[t]{2}{*}{$\begin{array}{c}\text { Hubungan dengan karyawan dan } \\
\text { pelanggan }\end{array}$} & $\begin{array}{l}\text { Sebagai inkubator } \\
\text { bisnis }\end{array}$ & $\begin{array}{c}\text { Para pesang tidak } \\
\text { memiliki fasilitas } \\
\text { serupa }\end{array}$ \\
\hline & & Bersifat kekeluargaan & $\begin{array}{c}\text { Sama dengan } \\
\text { kompetitor }\end{array}$ \\
\hline 4. & Website & $\begin{array}{l}\text { Memiliki website } \\
\text { sendiri }\end{array}$ & $\begin{array}{c}\text { Para pesaing tidak } \\
\text { memiliki fasilitas } \\
\text { serupa }\end{array}$ \\
\hline 5. & Social media & $\begin{array}{c}\text { Memiliki Instagram } \\
\text { dan facebook }\end{array}$ & $\begin{array}{l}\text { Fasilitas media sosial } \\
\text { yang lebih beragam }\end{array}$ \\
\hline \multirow[t]{2}{*}{6} & \multirow[t]{2}{*}{ Reputasi } & $\begin{array}{l}\text { Tempat yang } \\
\text { intagramble }\end{array}$ & $\begin{array}{c}\text { Kompetitor lebih } \\
\text { unggul }\end{array}$ \\
\hline & & $\begin{array}{c}\text { Ruang untuk } \\
\text { mengadakan acara }\end{array}$ & $\begin{array}{c}\text { Pesaing tidak } \\
\text { memiliki fasilitas } \\
\text { serupa }\end{array}$ \\
\hline
\end{tabular}

Tabel diatas menerangkan bahwa Sawala Space \& Cofe memiliki 13 keunggulan Internal Based Resource dibandingkan dengan 3 perusahaan pesaingnya (Rootspace, Nyoesdoel dan kafe Poma). 13 keunggulan tersebut antara lain sebagai berikut:

1. Kapasitas gedung lebih besar dari para pesaingnya

2. Kursi tersedia lebih banyak dari pesaingnya

3. Router Wi-Fi lebih banyak di banding pesaing

4. Peralatan makan lebih banyak dibanding pesaing

5. Peralatan dapur lebih banyak dibanding pesaing
6. Kulkas lebih banyak dibanding pesaing

7. Memiliki perpustakaan mini yang tidak dimiliki pesaing

8. Memiliki room meeting lebih besar dibanding pesaing

9. Lokasi lebih strategis dibanding pesaing

10. Memiliki relasi yang banyak dibanding pesaing

11. Memiliki Inkubator bisnis yang tidak dimiliki pesaing

12. Memiliki website yang tidak dimiliki pesaing

13. Memiliki tempat acara yang lebih besar dibanding pesaing 


\section{ENTREPRENEUR}

\section{Jurnal Bisnis Manajemen Dan Kewirausahaan}

\section{Program Studi Manajemen Fakultas Ekonomika dan Bisnis Universitas Majalengka}

Published every January and July e-ISSN : (Proses), p-ISSN: 2723-1941

Available online http://ejournal.unma.ac.id/index.php/entrepreneur

\subsection{Analisis VRIO}

Analisis VRIO bertujuan untuk menganalisis kemampuan sumber daya yang

dimiliki oleh Sawala sendiri untuk bisa bersaing secara bekelanjutan dan mampu bertahan menghadapi para pesaing nantinya.

\begin{tabular}{|c|c|c|c|c|c|c|c|}
\hline No & Capabilities & Value & Rare & $\begin{array}{l}\text { Costly } \\
\text { to } \\
\text { imitate }\end{array}$ & $\begin{array}{l}\text { Non } \\
\text { Substituable }\end{array}$ & $\begin{array}{l}\text { Competitive } \\
\text { Consequence }\end{array}$ & $\begin{array}{l}\text { Performance } \\
\text { Implications }\end{array}$ \\
\hline 1 & $\begin{array}{l}\text { Kapasitas } \\
\text { Gedung } \\
\text { untuk } 100 \\
\text { orang }\end{array}$ & Yes & Yes & Yes & No & $\begin{array}{l}\text { Competitive } \\
\text { partly }\end{array}$ & $\begin{array}{l}\text { Averange } \\
\text { Return }\end{array}$ \\
\hline 2. & $\begin{array}{l}\text { Usia } \\
\text { ekonomis } \\
\text { gedung } \\
\text { selama } \\
\text { tahun }\end{array}$ & Yes & No & Yes & No & $\begin{array}{l}\text { Competitive } \\
\text { disadvantage }\end{array}$ & $\begin{array}{l}\text { Averange } \\
\text { Return }\end{array}$ \\
\hline 3. & $\begin{array}{ll}\text { Gedung } & 1 \\
\text { lantai } & \end{array}$ & Yes & No & No & No & $\begin{array}{l}\text { Competitive } \\
\text { Disadvantage }\end{array}$ & $\begin{array}{l}\text { Averange } \\
\text { Return }\end{array}$ \\
\hline 4. & $\begin{array}{l}\text { Parkiran } \\
\text { untuk } 3 \text { mobil }\end{array}$ & Yes & No & No & No & $\begin{array}{l}\text { Competitive } \\
\text { Disadvantage }\end{array}$ & $\begin{array}{l}\text { Averange } \\
\text { Return }\end{array}$ \\
\hline 5. & $\begin{array}{ll}\text { Parkiran } & \\
\text { untuk } & 30 \\
\text { motor } & \end{array}$ & Yes & No & No & No & $\begin{array}{l}\text { Competitive } \\
\text { Disadvantage }\end{array}$ & $\begin{array}{l}\text { Averange } \\
\text { Return }\end{array}$ \\
\hline 6. & $\begin{array}{l}\text { Usia } \\
\text { ekonomis } \\
\text { parkiran } \\
\text { tahun }\end{array}$ & Yes & Yes & No & No & $\begin{array}{l}\text { Competitive } \\
\text { Disadvantage }\end{array}$ & $\begin{array}{l}\text { Averange } \\
\text { Return }\end{array}$ \\
\hline 7. & 25 meja & Yes & No & No & No & $\begin{array}{l}\text { Competitive } \\
\text { Disadvantage }\end{array}$ & $\begin{array}{l}\text { Averange } \\
\text { Return }\end{array}$ \\
\hline 8. & 66 kursi & Yes & Yes & Yes & No & $\begin{array}{l}\text { Competitive } \\
\text { Partly }\end{array}$ & $\begin{array}{l}\text { Averange } \\
\text { Return }\end{array}$ \\
\hline 9. & $\begin{array}{l}\text { Umur } \\
\text { ekonomis } \\
\text { meja dan } \\
\text { kursi } 4 \text { tahun }\end{array}$ & Yes & Yes & No & No & $\begin{array}{l}\text { Competitive } \\
\text { Disadvantage }\end{array}$ & $\begin{array}{l}\text { Averange } \\
\text { Return }\end{array}$ \\
\hline 10. & $\begin{array}{l}\text { Kesepatan } \\
\text { wifi } 20 \text { dan } \\
50 \text { mbps }\end{array}$ & Yes & Yes & No & No & $\begin{array}{l}\text { Competitive } \\
\text { Disadvantage }\end{array}$ & $\begin{array}{l}\text { Averange } \\
\text { Return }\end{array}$ \\
\hline 11. & $\begin{array}{l}\text { Ada } 3 \text { rauter } \\
\text { wifi }\end{array}$ & Yes & Yes & Yes & No & $\begin{array}{l}\text { Competitive } \\
\text { Partly }\end{array}$ & $\begin{array}{l}\text { Averange } \\
\text { Return }\end{array}$ \\
\hline 12. & $\begin{array}{l}\text { Ada } 17 \text { mesin } \\
\text { kopi }\end{array}$ & Yes & Yes & No & No & $\begin{array}{l}\text { Competitive } \\
\text { Disadvantage }\end{array}$ & $\begin{array}{l}\text { Averange } \\
\text { Return }\end{array}$ \\
\hline
\end{tabular}




\begin{tabular}{|c|c|c|c|c|c|c|c|}
\hline & Program St & $\begin{array}{l}\text { Jurna } \\
\text { udi Ma } \\
\text { Publish } \\
\text { Ava }\end{array}$ & $\begin{array}{r}\text { E] } \\
\text { Bisni } \\
\text { jemen } \\
\text { every J } \\
\text { ole onlir }\end{array}$ & $\begin{array}{l}\text { ITR } \\
\text { Man } \\
\text { akulta } \\
\text { uary anc } \\
\text { http://ej }\end{array}$ & $\begin{array}{l}\text { PRI } \\
\text { men } \\
\text { ronom } \\
\text { e-ISSI } \\
\text { 1.unma. }\end{array}$ & $\begin{array}{l}\text { JR } \\
\text { wirausahaan } \\
\text { snis Universitas } 1 \\
\text { p-ISSN: } 2723-1941 \\
\text { hp/entrepreneur }\end{array}$ & [ajalengka \\
\hline 13. & $\begin{array}{l}\text { Ada 93 set } \\
\text { peralatan } \\
\text { makan }\end{array}$ & Yes & Yes & Yes & No & $\begin{array}{l}\text { Competitive } \\
\text { Partly }\end{array}$ & $\begin{array}{l}\text { Averange } \\
\text { Return }\end{array}$ \\
\hline 14. & $\begin{array}{l}\text { Ada } 41 \text { set } \\
\text { peralatan } \\
\text { dapur }\end{array}$ & Yes & Yes & Yes & No & $\begin{array}{l}\text { Competitive } \\
\text { Partly }\end{array}$ & $\begin{array}{l}\text { Averange } \\
\text { Return }\end{array}$ \\
\hline 15. & $\begin{array}{l}\text { Bisa } \\
\text { menghasilkan } \\
30 \text { menu } \\
\text { dalam sehari }\end{array}$ & Yes & No & No & No & $\begin{array}{l}\text { Competitive } \\
\text { Disadvantage }\end{array}$ & $\begin{array}{l}\text { Averange } \\
\text { Return }\end{array}$ \\
\hline 16. & Memiliki 2 ac & Yes & Yes & No & No & $\begin{array}{l}\text { Competitive } \\
\text { Disadvantage }\end{array}$ & $\begin{array}{l}\text { Averange } \\
\text { Return }\end{array}$ \\
\hline 17. & $\begin{array}{l}\text { Memiliki } 1 \\
\text { kipas angin }\end{array}$ & Yes & No & No & No & $\begin{array}{l}\text { Competitive } \\
\text { Disadvantage }\end{array}$ & $\begin{array}{l}\text { Averange } \\
\text { Return }\end{array}$ \\
\hline 18. & $\begin{array}{l}\text { Memiliki } 5 \\
\text { lemari } \\
\text { pendingin }\end{array}$ & Yes & Yes & Yes & No & $\begin{array}{l}\text { Competitive } \\
\text { Partly }\end{array}$ & $\begin{array}{l}\text { Averange } \\
\text { Return }\end{array}$ \\
\hline 19. & $\begin{array}{l}\text { Memiliki } \\
\text { mushola } \\
\text { dengan } \\
\text { kapasitas } \quad 5 \\
\text { orang }\end{array}$ & Yes & No & No & No & $\begin{array}{l}\text { Competitive } \\
\text { Disadvantage }\end{array}$ & $\begin{array}{l}\text { Averange } \\
\text { Return }\end{array}$ \\
\hline 20. & $\begin{array}{l}\text { Memiliki } \\
\text { perpustakaan } \\
\text { dengan } \\
\text { kapasitas } 15 \\
\text { orang }\end{array}$ & Yes & Yes & No & Yes & $\begin{array}{l}\text { Competitive } \\
\text { Partly }\end{array}$ & $\begin{array}{l}\text { Averange } \\
\text { Return }\end{array}$ \\
\hline 21. & $\begin{array}{l}\text { Memiliki } \\
\text { toilet } \\
\text { kapasitas } \\
\text { orang }\end{array}$ & & No & No & No & $\begin{array}{l}\text { Competitive } \\
\text { Disadvantage }\end{array}$ & $\begin{array}{l}\text { Averange } \\
\text { Return }\end{array}$ \\
\hline 22. & $\begin{array}{l}\text { Memiliki } \\
\text { room meeting } \\
\text { kapasitas } 20 \\
\text { orang }\end{array}$ & Yes & Yes & No & Yes & $\begin{array}{l}\text { Competitive } \\
\text { Partly }\end{array}$ & $\begin{array}{l}\text { Averange } \\
\text { Return }\end{array}$ \\
\hline 23. & $\begin{array}{l}\text { Mesin kasir } \\
\text { ada } 1\end{array}$ & Yes & No & No & No & $\begin{array}{l}\text { Competitive } \\
\text { Disadvantage }\end{array}$ & $\begin{array}{l}\text { Averange } \\
\text { Return }\end{array}$ \\
\hline 24. & $\begin{array}{l}\text { Usia } \\
\text { ekonomis } \\
\text { mesin kasir } 5 \\
\text { tahun }\end{array}$ & Yes & No & No & No & $\begin{array}{l}\text { Competitive } \\
\text { Disadvantage }\end{array}$ & $\begin{array}{l}\text { Averange } \\
\text { Return }\end{array}$ \\
\hline
\end{tabular}




\begin{tabular}{|c|c|c|c|c|c|c|c|}
\hline & Program St & $\begin{array}{r}\text { Jurn } \\
\text { udi M: } \\
\text { Publis } \\
\text { Av: }\end{array}$ & $\begin{array}{r}\text { E] } \\
\text { Bisni } \\
\text { jemen } \\
\text { every J } \\
\text { ble onlir }\end{array}$ & $\begin{array}{l}\text { ITR } \\
\text { Man } \\
\text { akulta } \\
\text { uary anc } \\
\text { http://ej }\end{array}$ & $\begin{array}{l}\text { PR } \\
\text { men } \\
\text { zonom } \\
\text { e-ISSI } \\
\text { l.unma. }\end{array}$ & $\begin{array}{l}\text { JR } \\
\text { wirausahaan } \\
\text { isnis Universitas } 1 \\
\text { p-ISSN: 2723-1941 } \\
\text { hp/entrepreneur }\end{array}$ & Iajalengka \\
\hline 25. & $\begin{array}{l}\text { Mengadakan } \\
\text { live musik 2x } \\
\text { sebulan }\end{array}$ & Yes & No & No & No & $\begin{array}{l}\text { Competitive } \\
\text { Disadvantage }\end{array}$ & $\begin{array}{l}\text { Averange } \\
\text { Return }\end{array}$ \\
\hline 26. & $\begin{array}{l}\text { Lokasi yang } \\
\text { strategis }\end{array}$ & Yes & No & & No & $\begin{array}{l}\text { Sustained } \\
\text { Competitive } \\
\text { Advantage } \\
\end{array}$ & $\begin{array}{l}\text { Above } \\
\text { Averange } \\
\text { Return } \\
\end{array}$ \\
\hline 27. & Merek & Yes & No & Yes & No & $\begin{array}{l}\text { Competitive } \\
\text { Disadvantage }\end{array}$ & $\begin{array}{l}\text { Averange } \\
\text { Return }\end{array}$ \\
\hline 28. & $\begin{array}{l}\text { Memiliki } \\
\text { relasi dengan } \\
\text { komunitas } \\
\text { dan vendor }\end{array}$ & Yes & Yes & Yes & Yes & $\begin{array}{l}\text { Sustained } \\
\text { Competitive } \\
\text { Advantage }\end{array}$ & $\begin{array}{l}\text { Above } \\
\text { Averange } \\
\text { Return }\end{array}$ \\
\hline 29. & $\begin{array}{l}\text { Sebagai } \\
\text { incubator } \\
\text { bisnis }\end{array}$ & Yes & Yes & Yes & Yes & $\begin{array}{l}\text { Sustained } \\
\text { Competitive } \\
\text { Advantage }\end{array}$ & $\begin{array}{l}\text { Above } \\
\text { Averange } \\
\text { Return }\end{array}$ \\
\hline 30. & $\begin{array}{l}\text { Bersifat } \\
\text { kekeluargaa }\end{array}$ & Yes & Yes & Yes & Yes & $\begin{array}{l}\text { Sustained } \\
\text { Competitive } \\
\text { Advantage }\end{array}$ & $\begin{array}{l}\text { Above } \\
\text { Averange } \\
\text { Return } \\
\end{array}$ \\
\hline 31. & $\begin{array}{l}\text { Memiliki } \\
\text { website }\end{array}$ & Yes & Yes & Yes & Yes & $\begin{array}{l}\text { Sustained } \\
\text { Competitive } \\
\text { Advantage }\end{array}$ & $\begin{array}{l}\text { Above } \\
\text { Averange } \\
\text { Return }\end{array}$ \\
\hline 32. & Sosial media & Yes & No & No & No & $\begin{array}{l}\text { Competitive } \\
\text { Disadvantage }\end{array}$ & $\begin{array}{l}\text { Averange } \\
\text { Return }\end{array}$ \\
\hline 33. & Instagramble & Yes & No & No & No & $\begin{array}{l}\text { Competitive } \\
\text { Disadvantage }\end{array}$ & $\begin{array}{l}\text { Averange } \\
\text { Return }\end{array}$ \\
\hline 34. & $\begin{array}{l}\text { Reputasi } \\
\text { sebagai } \\
\text { tempat } \\
\text { acara/event }\end{array}$ & Yes & Yes & Yes & Yes & $\begin{array}{l}\text { Sustained } \\
\text { Competitive } \\
\text { Advantage }\end{array}$ & $\begin{array}{l}\text { Above } \\
\text { Averange } \\
\text { Return }\end{array}$ \\
\hline
\end{tabular}

Dari analisis VRIO tersebut diketahui bahwa, Sawala Space \& Café memiliki 13 keunggulan. Namun keunggulan tersebut bukan berarti selamanya tetapi hanya sementara, selama terjadi perubahan maka keunggulan tersebut dapat berubah. Analisis ini berdasarkan tingkat apakah resource dan capabilities yang dimiliki perusahaan tersebut memungkinkan untuk merespon peluang dan ancaman(valuable) dan apakah sumber daya tersebut langka dan sulit ditiru pesaing(rare).
Apabila sumber daya tersebut valuable dan rare maka akan terjadi keunggulan bersaing dan sumber daya tersebut susah untuk di tiru.

Maka dari itu sumber daya tersebut apabila bersifat sementara maka berarti bentuk penggantinya mudah didapatkan sedangkan apabila sumber daya tersebut valuable dan rare, dapat menjadi sumber daya kompetitif berkelanjutan. 


\section{ENTREPRENEUR}

\section{Jurnal Bisnis Manajemen Dan Kewirausahaan}

\section{Program Studi Manajemen Fakultas Ekonomika dan Bisnis Universitas Majalengka}

Published every January and July e-ISSN : (Proses), p-ISSN: 2723-1941

Available online http://ejournal.unma.ac.id/index.php/entrepreneur

Berdasarkan tabel diatas, yang termasuk data yang bersifat kompetitif pesaing sementara adalah

1. Kapasitas Gedung

2. Kapasitas kursi

3. Router Wi-Fi

4. Peralatan makan

5. Peralatan dapur

6. Lemari pendingin

7. Perpustakaan

8. Meeting room

\subsection{Analisis SCA}

Analisis SCA berguna untuk menganalisis sumber daya tangable dan intangible pada perusahaan sehingga dapat dimanfaatkan untuk mendapatkan keunggulan kompetitif berkelanjutan. Analisis VRIO tadi kemudian dilanjutkan menjadi analisis SCA dengan mengambil data yang terkait Sustainable Competitive Advantage di Sawala Space \& Café.

Tabel 4. Analisis SCA

\begin{tabular}{|l|l|}
\hline No. & SCA \\
\hline 1. & Lokasi Strategis \\
\hline 2. & Relasi \\
\hline 3. & Inkubator Bisnis \\
\hline 4. & Website \\
\hline 5. & Reputasi \\
\hline
\end{tabular}

Tabel diatas, menjelaskan tentang kapabilitas usaha Sawala Space \& Cofe yang memperoleh SCA (Sustainable Competitive Advantage). Berikut ini penjelasan lengkapnya:

1. Lokasi Strategis

Sawala Space \& Cofe memiliki lokasi strategis dibanding dengan pesaingnya dimana Sawala Space \& Cofe berada di dekat alun - alun Kab. Sumedang, dekat dengan Sekolah Menegah Atas Negeri 1
Sumedang, dekat dengan kantor pemerintahaan lama Kab. Sumedang. Sehingga ini menjadi daya Tarik tersendiri karena, dengan lokasi tersebut sesuai dengan target pasar dari Sawala Space \& Cofe yaitu anak remaja lanjut dewasa dan orang kantoran.

2. Relasi

Sawala Space \& Cofe memiliki relasi yang kuat. Di mana pemilik dari Sawala Space \& Cofe itu sendiri merupakan seorang yang berpengalaman di bidang bisnis dan memiliki banyak partner yang siap membantu untuk urusan bisnis sehingga disbanding dengan bisnis kedai kopi lainnya di kota Sumedang, ini akan menjadi daya Tarik tersendiri karena sering kali owner mengundang Bupati Sumedang ataupun Sekda Sumedang untuk dating ke Sawala Space \& Cofe untuk kegiatan tertentu. Sehingga ini menjadi diferensiasi dari Kedai Kopi di Sumedang, karena orang yang diundang bukan sembarang orang melainkan orang nomer 1 di Kabupaten Sumedang sendiri.

3. Inkubator Bisnis

Inkubator bisnis adalah dukungan bisnis untuk usaha start up atau baru dibentuk untuk bersaing di lini usahanya. Penulis menilai, bahwa Sawala Space \& Cofe karena memiliki relasi kuat dan Pendidikan yang tidak bias dipandang sebelah mata maka juga berkaitan dengan inkubator bisnis yang baik. Dimana karena Sawala Space \& Cofe ini baru berdiri sekitar 1 tahun lebih dan dapat terhitung baru disbanding 


\section{ENTREPRENEUR}

\section{Jurnal Bisnis Manajemen Dan Kewirausahaan}

Program Studi Manajemen Fakultas Ekonomika dan Bisnis Universitas Majalengka

Published every January and July e-ISSN : (Proses), p-ISSN: 2723-1941

Available online http://ejournal.unma.ac.id/index.php/entrepreneur

pesaingnya tetapi nyatanya dari segi

SCA mampu mengungguli pesaing.

4. Website

Website Sawala Space \& Cofe adalah www.sawala.space dimana dalam website tersebut menyajikan informasi seputar Sawala Space \& Cofe hingga daftar menu dan harga. Dibandingkan dengan pesaingnya, Sawala Space \& Cofe adalah satu satunya yang memiliki website. Makannya ini disebut rare \& valuable. Dimana lagi - lagi Sawala Space \& Cofe berada selangkah didepan dibanding para pesaingnya. Sawala Space \& Cofe memiliki kesan lebih professional, adaptif dan dinamis dibanding pesaingnya. Website ini sangat memudahkan pelanggan untuk membeli dan juga menjadi infografis bagi pelanggan supaya lebih mengenal apa itu Sawala Space \& Cofe.

5. Reputasi

Sawala Space \& Cofe memiliki kesan yang professional, adaptif dan dinamis. Penulis menganggap professional karena Sawala Space \& Cofe memiliki managemen tim yang baik, selain itu juga memiliki pengetahuan yang terampil agar masakan ataupun minuman yang dijual itu dapat sesuai target pasarnya. Café sawala juga sangat adaptif dimana selalu menyesuaikan diri dengan kebutuhan pelanggan. Misalnya pada saat ini ada kopi yang sedang booming maka manajemen Sawala Space \& Cofe mencoba menggali informasi dan melakukan peniruan produk tersebut. Makannya daftar menu
Sawala Space \& Cofe sangat banyak dan bervariasi, apabila dibandingkan dengan kedai kopi lain, Sawala Space \& Cofe memiliki daftar menu yang luar biasa banyaknya. Lalu penulis menganggap Sawala Space \& Cofe sangat adaptif karena mampu menyesuaikan diri dan bertahan di kondidi pandemic ini walaupun terbilang kedai kopi baru 1 tahun lebih berdiri yang biasanya rentan untuk gulung tikar.

\subsection{Analisis TOWS(analisis eksternal)}

Dalam analisis ini, mengidentifikasi peluang - peluang dan ancaman - ancaman yang berasal dari lingkungan eksternal perusahaan sehingga akan sangat bermanfaat bagi perusahaan apabila melakukan analisis ini karena perusahaan akan tahu kondisi eksternalnya serta bagaimana cara merencanakan strategi supaya terhindar/meminimalisir dari dampak ancaman luar tersebut.

Tabel 5. Analisis TOWS

\begin{tabular}{|l|c|l|}
\hline \multicolumn{3}{|c|}{ Keterangan } \\
\hline $\begin{array}{l}\text { Sangat } \\
\text { Mengancam }\end{array}$ & 1 & $\begin{array}{l}\text { Sangat Tidak } \\
\text { Penting }\end{array}$ \\
\hline Mengancam & 2 & $\begin{array}{l}\text { Tidak } \\
\text { Penting }\end{array}$ \\
\hline Biasa saja & 3 & Biasa Saja \\
\hline $\begin{array}{l}\text { Tidak } \\
\text { Mengancam }\end{array}$ & 4 & Penting \\
\hline $\begin{array}{l}\text { Sangat Tidak } \\
\text { Mengancam }\end{array}$ & 5 & $\begin{array}{l}\text { Sangat } \\
\text { Penting }\end{array}$ \\
\hline
\end{tabular}

dalam $\begin{array}{rrr}\text { Tahapan yang } & \text { dilakukan } & \text { peneliti } \\ \text { menganalisis } & \text { TOWS } & \text { yaitu }\end{array}$ menganalisis faktor eksternal berupa ancaman(threats) dan peluang(opportunity) dilanjutkan dengan melihat faktor internal yang bersunggungan dengan lingkungan 


\section{ENTREPRENEUR}

\section{Jurnal Bisnis Manajemen Dan Kewirausahaan}

Program Studi Manajemen Fakultas Ekonomika dan Bisnis Universitas Majalengka

Published every January and July e-ISSN : (Proses), p-ISSN: 2723-1941

Available online http://ejournal.unma.ac.id/index.php/entrepreneur

eksternal seperti kelemahan (weakness) dan kekuatan (strength) yang dimiliki Sawala Space \& Cofe. Dilanjutkan dengan penilaian(scoring) dan terakhir menggunakan

Tabel 6. Analisis Ancaman Sawala Space \& Cafe

\begin{tabular}{|l|l|l|l|l|l|l|l|l|l|l|l|}
\hline No. & \multicolumn{3}{|c|}{ Indikator Ancaman } & \multicolumn{4}{|c|}{ Kondisi Saat Ini } & \multicolumn{4}{c|}{ Urgensi Pelanggan } \\
\cline { 2 - 11 } & & 1 & 2 & 3 & 4 & 5 & 1 & 2 & 3 & 4 & 5 \\
\hline 1 & $\begin{array}{l}\text { Pesaing dengan menu yang lebih } \\
\text { menarik dan fasilitas yang lebih } \\
\text { bagus }\end{array}$ & & & & & & & & & & \\
\hline 2 & $\begin{array}{l}\text { Adanya pandemic Covid-19 yang } \\
\text { belum pasti kapan akan selesai }\end{array}$ & & & & & & & & & & \\
\hline 3 & $\begin{array}{l}\text { Kebosenan Costumer dengan } \\
\text { suasana tempat atau menu } \\
\text { makanan }\end{array}$ & & & & & & & & & \\
\hline 4 & $\begin{array}{l}\text { Harga bahan baku yang } \\
\text { cenderung meningkat }\end{array}$ & & & & & & & & & \\
\hline 5 & Akan banyaknya pesaing baru & & & & & & & & & & \\
\hline
\end{tabular}

Tabel 7. Analisis Peluang Sawala Space \& Cafe

\begin{tabular}{|c|c|c|c|c|c|c|c|c|c|c|}
\hline \multirow[t]{2}{*}{ No. } & \multirow{2}{*}{ Indikator Peluang } & \multicolumn{4}{|c|}{ Kondisi Saat Ini } & \multicolumn{5}{|c|}{ Urgensi Pelanggan } \\
\hline & & \begin{tabular}{l|l}
1 & 2 \\
\end{tabular} & 3 & 4 & 5 & 1 & 2 & 3 & 4 & 5 \\
\hline 1 & $\begin{array}{l}\text { Gaya hidup anak muda suka } \\
\text { nongkrong }\end{array}$ & & & & & & & & & \\
\hline 2 & $\begin{array}{l}\text { Tingkat konsumsi kopi yang } \\
\text { tinggi }\end{array}$ & & & & & & & & & \\
\hline 3 & $\begin{array}{l}\text { Tersedia dalam go food dan grab } \\
\text { food }\end{array}$ & & & & & & & & & \\
\hline 4 & Memiliki pelanggan loyal & & & & & & & & & \\
\hline 5 & $\begin{array}{l}\text { Promosi oleh pelanggan(tidak } \\
\text { direncanakan) }\end{array}$ & & & & & & & & & \\
\hline
\end{tabular}

Tabel 8. Analisis Kelemahan Sawala Space \& Cafe

\begin{tabular}{|l|l|l|l|l|l|l|l|l|l|l|l|}
\hline No. & \multicolumn{3}{|c|}{ Indikator Kelemahan } & \multicolumn{4}{|c|}{ Kondisi Saat Ini } & \multicolumn{5}{|c|}{ Urgensi Pelanggan } \\
\hline & & 1 & 2 & 3 & 4 & 5 & 1 & 2 & 3 & 4 & 5 \\
\hline 1 & Promosi kurang masif & & & & & & & & & & \\
\hline 2 & $\begin{array}{l}\text { Tingkat awareness dibawah } \\
\text { pesaing }\end{array}$ & & & & & & & & & & \\
\hline 3 & Belum ada menu ciri khas & & & & & & & & & & \\
\hline
\end{tabular}




\section{ENTREPRENEUR}

Jurnal Bisnis Manajemen Dan Kewirausahaan

Program Studi Manajemen Fakultas Ekonomika dan Bisnis Universitas Majalengka

Published every January and July e-ISSN : (Proses), p-ISSN: 2723-1941

Available online http://ejournal.unma.ac.id/index.php/entrepreneur

\begin{tabular}{|l|l|l|l|l|l|l|l|l|l|l|l|}
\hline 4 & Branding kurang masif & & & & & & & & & & \\
\hline 5 & Target pasar terbatas & & & & & & & & & & \\
\hline
\end{tabular}

Tabel 9. Analisis Kekuatan Sawala Space \& Cafe

\begin{tabular}{|l|l|l|l|l|l|l|l|l|l|l|l|}
\hline \multirow{2}{*}{ No. } & \multicolumn{3}{|c|}{ Indikator Kekuatan } & \multicolumn{3}{|c|}{ Kondisi Saat Ini } & \multicolumn{5}{c|}{ Urgensi Pelanggan } \\
\hline & & 1 & 2 & 3 & 4 & 5 & 1 & 2 & 3 & 4 & 5 \\
\hline 1 & Lokasi Strategis & & & & & & & & & & \\
\hline 2 & Produk Bervariasi & & & & & & & & & & \\
\hline 3 & Tempat yang luas & & & & & & & & & & \\
\hline 4 & Prasarana bervariasi & & & & & & & & & & \\
\hline 5 & Website usaha tersendiri & & & & & & & & & & \\
\hline
\end{tabular}

Sumber: Diolah peneliti(2021)

Berdasarkan tabel analisis TOWS

Adapun pertimbangan factor Sawala Space \& Café, maka didapatkan ancaman - ancaman dan peluang - peluang yang dihadapi Sawala Space \& Café berdasarkan penilaian kondisi saat ini dan penanganannnya. Ancaman - ancaman tersebut antara lain: 1). Adanya pandemic Covid-19 yang belum pasti kapan akan selesai, 2). Pesaing dengan menu yang lebih menarik dan fasilitas yang lebih bagus. Selain Ancaman, usaha Sawala Space \& Cofe juga memiliki peluang yaitu:1). Memiliki pelanggan yang loyal, 2). Testimoni/promosi gratis dari pelanggan yang tidak direncanakan. internal terhadap factor eksternal terdiri dari kelemahan dan kekuatan dari Sawala Space \& Cofe. Kelemahan yang dimiliki oleh 1). Branding kurang massif, 2). Belum ada menu ciri khas. Selanjutnya kekuatan terbesar Sawala Space \& Cofe yaitu 1). Prasarana bervariasi, 2). Website usaha sendiri

\subsection{Analisis Stretegi Terpilih}

Analisis ini diberikan sesuai dengan isu permasalahan yang dihadapi perusahaan. Usulan ini dilakukan dengan melakukan pencocokan SCA untuk menentukan strategi terpilih sehingga dapat diketahui sejauh mana isu tersebut memiliki keterkaitan dengan SCA.

Tabel 10. Analisis Usulan Program

\begin{tabular}{|l|l|l|l|l|l|l|l|}
\hline No. & $\begin{array}{l}\text { Hasil analisis } \\
\text { TOWS terkait }\end{array}$ & $\begin{array}{l}\text { Usulan } \\
\text { program }\end{array}$ & SCA 1 & SCA 2 & SCA 3 & SCA 4 & SCA 5 \\
\hline 1 & $\begin{array}{l}\text { Adanya pandemic } \\
\text { Covid-19 yang } \\
\text { belum pasti kapan } \\
\text { akan selesai }\end{array}$ & - & $\checkmark$ & - & - & $\checkmark$ \\
\hline 2 & $\begin{array}{l}\text { Pesaing dengan } \\
\text { menu yang lebih } \\
\text { menarik dan } \\
\text { fasilitas yang lebih } \\
\text { bagus }\end{array}$ & $\begin{array}{l}\text { Program } \\
\text { Process } \\
\text { Reengineering }\end{array}$ & - & - & $\checkmark$ & - & $\checkmark$ \\
\hline
\end{tabular}




\begin{tabular}{|c|c|c|c|c|c|c|c|}
\hline & $\begin{array}{r}\text { Jurn } \\
\text { Program Studi M: } \\
\text { Publis } \\
\text { Av }\end{array}$ & $\begin{array}{l}\text { ENTRE } \\
\text { al Bisnis Manaje } \\
\text { anajemen Fakultas E } \\
\text { hed every January and July } \\
\text { ailable online http://ejourn }\end{array}$ & $\begin{array}{l}\text { PRI } \\
\text { men } \\
\text { onomi } \\
\text { e-ISSN } \\
\text { l.unma. }\end{array}$ & $\begin{array}{l}\text { EU } \\
\text { Kev } \\
\text { n Bis } \\
\text { es), p- } \\
\text { dex.ph }\end{array}$ & $\begin{array}{l}\text { ISaha } \\
\text { iversi } \\
2723-19 \\
\text { preneur }\end{array}$ & ajalen & \\
\hline 3 & $\begin{array}{l}\text { Prasarana } \\
\text { bervariasi }\end{array}$ & $\begin{array}{l}\text { Optimalisasi } \\
\text { event untuk } \\
\text { meningkatkan } \\
\text { penggunaan } \\
\text { prasarana }\end{array}$ & - & $V$ & - & - & $\checkmark$ \\
\hline 4 & $\begin{array}{l}\text { Website usaha } \\
\text { sendiri }\end{array}$ & $\begin{array}{l}\text { Oprimalisasi } \\
\text { UI/UX }\end{array}$ & - & - & - & $\checkmark$ & - \\
\hline 5 & $\begin{array}{l}\text { Memiliki } \\
\text { pelanggan } \quad \text { yang } \\
\text { loyal }\end{array}$ & $\begin{array}{l}\text { 1). Program buy } \\
2 \text { get } 1 \text { masker. } \\
\text { 2). Memberi } \\
\text { potingan harga } \\
\text { atau discount } \\
\text { 3). Membuat } \\
\text { program Sawala } \\
\text { Loyalty(dengan } \\
\text { menjadi member } \\
\text { Sawala akan } \\
\text { mendapatkan } \\
\text { banyak promo } \\
\text { terbatas) }\end{array}$ & $V$ & $\checkmark$ & - & $\checkmark$ & $V$ \\
\hline 6 & $\begin{array}{l}\text { Testimoni/promosi } \\
\text { gratis dari } \\
\text { pelanggan yang } \\
\text { tidak direncanakan. }\end{array}$ & $\begin{array}{l}\text { Program affiliate } \\
\text { marketing(Sawa } \\
\text { la Space \& Cofe } \\
\text { memberikan } \\
\text { reward kepada } \\
\text { pelanggan yang } \\
\text { membawa } \\
\text { pelanggan baru) }\end{array}$ & - & $V$ & $V$ & - & $V$ \\
\hline 7 & $\begin{array}{l}\text { Branding kurang } \\
\text { massif }\end{array}$ & $\begin{array}{l}\text { Membuat tagline } \\
\text { menarik }\end{array}$ & - & $\checkmark$ & - & - & $V$ \\
\hline 8 & $\begin{array}{l}\text { Belum ada menu } \\
\text { ciri khas }\end{array}$ & $\begin{array}{l}\text { Membuat } \\
\text { konsep produk } \\
\text { sesuai branding } \\
\text { Sawala Space \& } \\
\text { Cofe }\end{array}$ & - & $\checkmark$ & - & - & $\checkmark$ \\
\hline
\end{tabular}

Sumber: Diolah penulis(2021)

\subsection{Usulan Strategi Terpilih}

Dari banyaknya program yang ada, dipilih 1(satu) atau beberapa strategi yang bisa memaksimalkan kinerja dan membantu mengatasi masalah. Strategi terpilih tersebut adalah

1. Program buy 2 get 1 masker.
2. Memberi potongan harga atau discount

3. Membuat program Sawala Loyalty(dengan menjadi member Sawala akan mendapatkan banyak promo terbatas)

4.7 Analisis Penerapan Usulan program 


\section{ENTREPRENEUR}

Jurnal Bisnis Manajemen Dan Kewirausahaan

Program Studi Manajemen Fakultas Ekonomika dan Bisnis Universitas Majalengka

Published every January and July e-ISSN : (Proses), p-ISSN: 2723-1941

Available online http://ejournal.unma.ac.id/index.php/entrepreneur

\section{Usulan program memerlukan}

komponen yang menunjang keberhasilan

program tersebut dimana memuat langkah yang jelas serta tujuan yang pasti. Berikut ini tabel penjelasan proses bisnis dari setiap strategi.

\section{Usulan Program: Program buy 2 get 1 masker}

\begin{tabular}{|c|c|c|}
\hline Proses Bisnis & Komponen & Indikator \\
\hline \multirow[t]{3}{*}{ Input } & 1. Pengetahuan & $\begin{array}{l}\text { Melakukan } \\
\begin{array}{l}\text { analisis } \\
\text { pelanggan serta analisis }\end{array} \\
\text { perusahaan. }\end{array}$ \\
\hline & 2. Biaya & $\begin{array}{l}\text { Mengetahui vendor masker dengan } \\
\text { harga murah. }\end{array}$ \\
\hline & 3. Informasi & $\begin{array}{l}\text { Mengetahui desain dan bentuk apa yang } \\
\text { akan digunakan }\end{array}$ \\
\hline \multirow[t]{2}{*}{ Proses } & $\begin{array}{l}\text { 1. Menghubungi vendor terkait untuk } \\
\text { merancang, mendesain dan membuat } \\
\text { masker dengan biaya relative murah. }\end{array}$ & $\begin{array}{l}\text { Masker sesuai dengan konsep branding } \\
\text { Sawala Space \& Cofe }\end{array}$ \\
\hline & $\begin{array}{l}\text { 2. Membuat kampanye buy } 2 \text { get } 1 \\
\text { masker yang dipublikasikan di sosial } \\
\text { media }\end{array}$ & $\begin{array}{l}\text { Terbentuk awareness dan daya Tarik } \\
\text { pelanggan }\end{array}$ \\
\hline \multirow[t]{2}{*}{ Output } & $\begin{array}{l}\text { 1. Pelangan membeli minimal } 2 \\
\text { produk kopi }\end{array}$ & Penjualan kopi meningkat minimal 50\% \\
\hline & $\begin{array}{l}\text { 2. Peningkatkan penggunaan masker } \\
\text { dilingkungan Sawala Space \& } \\
\text { Cofe. }\end{array}$ & $\begin{array}{l}\text { Rata - rata pelanggan menggunakan } \\
\text { masker Sawala Space \& Cofe ketika } \\
\text { berpergiaan minimal tingkat } \\
\text { penggunaan } 50 \% \text { dari total pembagian } \\
\text { masker gratis }\end{array}$ \\
\hline Outcome & $\begin{array}{l}\text { Kampanye Sawala Space \& Cofe } \\
\text { yang peduli sekitar dengan } \\
\text { pemberian masker gratis ke } \\
\text { pelanggan }\end{array}$ & $\begin{array}{l}\text { Nama baik dan citra Sawala Space } \& \\
\text { Cofe meningkat dibuktikan dengan data } \\
\text { minimal terjadi peningkatan sebesar } \\
30 \% \text { per tahun }\end{array}$ \\
\hline \multirow[t]{2}{*}{ Benefit } & \begin{tabular}{lrr|} 
1. Meningkatkan image & positif \\
dengan mendukung & pemerintah \\
dalam memperkecil & penularan \\
angka Covid-19 & melalui \\
pembagian masker gratis &
\end{tabular} & $\begin{array}{l}\text { Meningkatnya image positif yang } \\
\text { ditandai dengan interaksi antar Sawala } \\
\text { Space \& Cofe dengan pelanggan yang } \\
\text { lebih baik dibuktikan missal dalam } \\
\text { kolom komentar sosial media yang lebih } \\
\text { mengutarakan dukungan ke Sawala } \\
\text { Space \& Cofe. }\end{array}$ \\
\hline & $\begin{array}{l}\text { 2. Mempertahankan dan } \\
\text { meningkatnya jumlah pelanggan }\end{array}$ & $\begin{array}{l}\text { Minimal terjadi peningkatan penjualan } \\
\text { dan peningkatan pelanggan baru sebesar } \\
20 \% \text { per tahun }\end{array}$ \\
\hline Impact & $\begin{array}{l}\text { 1. Pelanggan senang karena Sawala } \\
\text { Space \& Cofe memberikan masker } \\
\text { gratis }\end{array}$ & $\begin{array}{l}\text { Terjadi komunikasi pemasaran yang } \\
\text { baik antara kedua belah pihak minimal } \\
30 \% \text { peningkatan engagement } \\
\text { dibuktikan melalui data per } 1 \text { tahun. }\end{array}$ \\
\hline
\end{tabular}




\begin{tabular}{|c|c|c|}
\hline \multicolumn{3}{|c|}{$\begin{array}{c}\text { ENTREPRENEUR } \\
\text { Jurnal Bisnis Manajemen Dan Kewirausahaan } \\
\text { Program Studi Manajemen Fakultas Ekonomika dan Bisnis Universitas Majalengka } \\
\text { Published every January and July e-ISSN : (Proses), p-ISSN: 2723-1941 } \\
\text { Available online http://ejournal.unma.ac.id/index.php/entrepreneur }\end{array}$} \\
\hline & $\begin{array}{l}\text { 2. Sawala Space \& Cofe dikenal } \\
\text { pelanggan sebagai kedai kopi yang } \\
\text { mampu mensejahterakan pelanggan }\end{array}$ & $\begin{array}{l}\text { Meningkatnya nama baik Sawala Space } \\
\text { \& Cofe dibuktikan dengan data minimal } \\
\text { terjadi peningkatan sebesar } 30 \% \text { per } \\
\text { tahun }\end{array}$ \\
\hline \multicolumn{3}{|c|}{ Usulan Program: Potongan harga(discount) } \\
\hline Proses Bisnis & Komponen & Indikator \\
\hline \multirow[t]{3}{*}{ Input } & 1. Pengetahuan & $\begin{array}{l}\text { Kemampuan perhitungan dan } \\
\text { merumuskan diskon }\end{array}$ \\
\hline & 2. Biaya & Tingkat pengalokasian dana yang tepat \\
\hline & 3. Informasi & Data terkait penjualan \\
\hline \multirow[t]{5}{*}{ Proses } & 1. Evaluasi penjualan produk & Analisis keuangan secara fundamental \\
\hline & 2. Mempelajari psikologi konsumen & $\begin{array}{l}\text { Kemampuan adaptif sesuai dengan } \\
\text { psikologis konsumen }\end{array}$ \\
\hline & 3. Membuat konsep potongan harga & $\begin{array}{l}\text { Terdapat strategi khusus yang } \\
\text { disesuaikan dengan rancangan anggaran } \\
\text { biaya }\end{array}$ \\
\hline & 4. Membuat poster dan promosi & Awareness pelanggan meningkat \\
\hline & $\begin{array}{l}\text { 5. Promosi ke sosial media dan } \\
\text { website }\end{array}$ & Sejumlah postingan terkait poster \\
\hline Output & $\begin{array}{l}\text { Voucher diskon dengan tingkatan } \\
\text { tertentu dan waktu tertentu }\end{array}$ & $\begin{array}{l}\text { 1. Voucher diskon sebesar } 5-10 \% \\
\text { pada event bulan bulan besar dan } \\
\text { tanggal cantik misalnya tanggal } 1 \\
\text { bulan januari. } \\
\text { 2. Dibagi atas tingkatan yang berbeda, } \\
\text { missal yang lebih sering repeat buying } \\
\text { by data akan bandatkan voucher lebih } \\
\text { banyak. }\end{array}$ \\
\hline \multirow[t]{3}{*}{ Outcome } & $\begin{array}{l}\text { 1.Rata - rata penggunaan voucher } \\
\text { discount sebanyak } 50 \% \text { dari jumlah } \\
\text { total supply voucher per minggu }\end{array}$ & $\begin{array}{l}\text { Rata - rata pelanggan menggunakan } \\
\text { voucher discount per transaksi minimal } \\
1 \text { kali per minggu }\end{array}$ \\
\hline & $\begin{array}{l}\text { 2.Pelanggan melakukan pembelian } \\
\text { berulang }\end{array}$ & $\begin{array}{l}\text { Meningkatnya penjualan produk per } \\
\text { pelanggan minimal } 30 \% \text { per tahun. }\end{array}$ \\
\hline & $\begin{array}{l}\text { 3.Perubahan psikologis dan pola } \\
\text { belanja pelanggan }\end{array}$ & $\begin{array}{l}\text { Pelanggan berada pada tingkatan } \\
\text { engagement dan mempromosikan } \\
\text { produk. Dibuktikan dengan data } \\
\text { minimal terjadi peningkatan } \\
\text { engagement } 30 \% \text { per tahun. }\end{array}$ \\
\hline \multirow[t]{2}{*}{ Benefit } & $\begin{array}{l}\text { 1. Konsumen membeli banyak } \\
\text { produk }\end{array}$ & $\begin{array}{l}\text { Penjualan meningkat, pembeli } \\
\text { meningkat. Dibuktikan dengan data } \\
\text { minimal 20\% per tahun. }\end{array}$ \\
\hline & 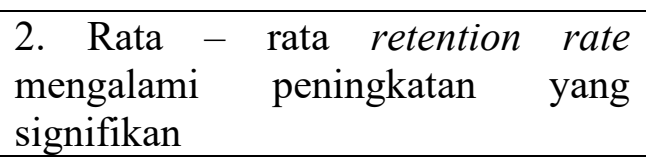 & Rata - rata retention rate diatas $50 \%$ \\
\hline
\end{tabular}




\begin{tabular}{|c|c|c|}
\hline \multicolumn{3}{|c|}{$\begin{array}{c}\text { ENTREPRENEUR } \\
\text { Jurnal Bisnis Manajemen Dan Kewirausahaan } \\
\text { Program Studi Manajemen Fakultas Ekonomika dan Bisnis Universitas Majalengka } \\
\text { Published every January and July e-ISSN : (Proses), p-ISSN: 2723-1941 } \\
\text { Available online http://ejournal.unma.ac.id/index.php/entrepreneur }\end{array}$} \\
\hline & 3. Meningkatkan rating perusahaan & $\begin{array}{l}\text { Minimal mendapat rating bintang } 4 \text { di } \\
\text { aplikasi google maps, go food dan grab } \\
\text { food }\end{array}$ \\
\hline \multirow[t]{2}{*}{ Impact } & $\begin{array}{l}\text { 1. Pelanggan } \quad \text { mendapatkan } \\
\text { keuntungan berupa potongan harga. }\end{array}$ & $\begin{array}{l}\text { Pelanggan merasa senang, dibuktikan } \\
\text { melalui survey tingkat kesenangan } \\
\text { pelanggan minimal terjadi peningkatan } \\
\text { sebesar } 20 \% \text { per tahun. }\end{array}$ \\
\hline & $\begin{array}{l}\text { 2. Keuntungan jangka pendek bagi } \\
\text { pelanggan untuk membeli produk } \\
\text { saat harga discont }\end{array}$ & $\begin{array}{l}\text { Adanya perilaku konsumen untuk } \\
\text { menjadi promotor Sawala Space \& Cofe } \\
\text { tanpa di bayar. }\end{array}$ \\
\hline \multicolumn{3}{|c|}{ Usulan Program: Program Sawala Loyalty } \\
\hline Proses Bisnis & Komponen & Indikator \\
\hline \multirow[t]{3}{*}{ Input } & 1. Pengetahuan & $\begin{array}{l}\text { 1. Mempelajari pemberian loyalty yang } \\
\text { baik kepada pelanggan }\end{array}$ \\
\hline & 2. Biaya & $\begin{array}{l}\text { Adanya biaya beban khusus untuk } \\
\text { program ini dengan dibuat rancangan } \\
\text { biaya yang sesuai dengan kemampuan } \\
\text { perusahaan }\end{array}$ \\
\hline & 3. Informasi & $\begin{array}{l}\text { Cross cek dengan program loyalitas } \\
\text { pelanggan perusahaan lain }\end{array}$ \\
\hline \multirow[t]{4}{*}{ Proses } & $\begin{array}{l}\text { 1. Merancang konsep } \\
\text { loyalty(layanan apa saja yang akan } \\
\text { diberikan ke pelanggan) }\end{array}$ & $\begin{array}{l}\text { Terdapat layanan seperti promo - promo } \\
\text { tertentu, bonus - bonus, harga khusus } \\
\text { dan sebagainya }\end{array}$ \\
\hline & 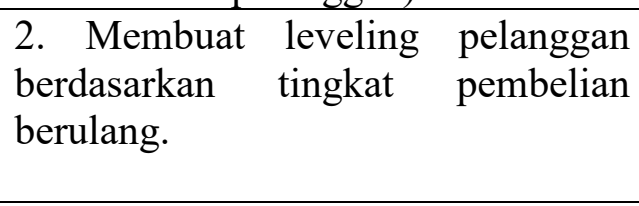 & $\begin{array}{l}\text { Pelanggan terkategori berdasarkan } \\
\text { tingkatan level yang berbeda sesuai } \\
\text { dengan seberapa banyak pembelian } \\
\text { berulangnya. }\end{array}$ \\
\hline & $\begin{array}{l}\text { 3. Membuat persyaratan \& ketentuan } \\
\text { leveling tersebut }\end{array}$ & $\begin{array}{l}\text { Berupa periode perhitungan loyalty } \\
\text { misalnya dihitung setiap } 2 \text { kali dalam } 1 \\
\text { tahun. Leveling tersebut ditentukan } \\
\text { dengan seberapa banyak pelanggan } \\
\text { melakukan transaksi,dll. }\end{array}$ \\
\hline & $\begin{array}{lll}\begin{array}{l}\text { 4. Pelaksanaan Sawala } \\
\text { menggunakan }\end{array} & \begin{array}{l}\text { Loyalty } \\
\text { website }\end{array} \\
\text { www.sawala.space } & \\
\end{array}$ & $\begin{array}{l}\text { Jumlah pengunjung dan pengguna } \\
\text { website meningkat, Sawala Loyalty } \\
\text { menjadi top click di website tersebut }\end{array}$ \\
\hline Output & Program berupa Sawala Loyalty & $\begin{array}{l}\text { Pelanggan tidak hanya bertambah } \\
\text { banyak dan repeat buying tetapi tertarik } \\
\text { untuk mendalami ekosistem Sawala } \\
\text { Space \& Cofe }\end{array}$ \\
\hline Outcome & $\begin{array}{l}\text { 1. Konsumen seolah - olah menjadi } \\
\text { bagian jajaran Sawala Space \& Cofe }\end{array}$ & $\begin{array}{l}\text { Pelanggan menjadi lebih atraktif dengan } \\
\text { pekerja ataupun owner dari Sawala } \\
\text { Space \& Cofe itu sendiri }\end{array}$ \\
\hline
\end{tabular}




\begin{tabular}{|c|c|c|}
\hline \multicolumn{3}{|c|}{$\begin{array}{c}\text { ENTREPRENEUR } \\
\text { Jurnal Bisnis Manajemen Dan Kewirausahaan } \\
\text { Program Studi Manajemen Fakultas Ekonomika dan Bisnis Universitas Majalengka } \\
\text { Published every January and July e-ISSN : (Proses), p-ISSN: 2723-1941 } \\
\text { Available online http://ejournal.unma.ac.id/index.php/entrepreneur }\end{array}$} \\
\hline & $\begin{array}{l}2 . \quad \text { Konsumen tidak hanya } \\
\text { dipertahankan tetapi juga diberikan } \\
\text { benefit yang menguntungkan }\end{array}$ & $\begin{array}{l}\text { Meningkatnya kesejahteraan konsumen } \\
\text { melalui program Sawala Loyalty }\end{array}$ \\
\hline \multirow[t]{2}{*}{ Benefit } & $\begin{array}{l}\text { 1. Perusahaan mempertahankan } \\
\text { pelanggan lama }\end{array}$ & $\begin{array}{l}\text { Terjadi peningkatan retention rate } \\
\text { sebesar } 50 \%\end{array}$ \\
\hline & $\begin{array}{l}\text { 2. Perusahaan mendapatkan } \\
\text { pelanggan baru }\end{array}$ & $\begin{array}{l}\text { Sawala Space \& Cofe mendapatkan } \\
\text { pelanggan baru rata }- \text { rata } 10 \% \\
\text { pelanggan baru per bulan dari setiap lini } \\
\text { produk kopi. }\end{array}$ \\
\hline \multirow[t]{2}{*}{ Impact } & $\begin{array}{l}\text { 1. Optimalisasi hubungan antara } \\
\text { pelanggan dengan Sawala Space \& } \\
\text { Cafe }\end{array}$ & $\begin{array}{l}\text { Sawala Space \& Café memiliki } \\
\text { ekosistem yang tidak hanya terpaku } \\
\text { pada penjualan produk saja tetapi juga } \\
\text { memikirkan banyak faktor salah } \\
\text { satunya hubungan antar pelangan dan } \\
\text { penjual. Optimalisasi tersebut dapat } \\
\text { terwujud dengan peningkatan program } \\
\text { Sawala Loyalty dari tahun ke tahun. } \\
\text { Optimalisasi ini dibuktikan by data } \\
\text { minimal terjadi peningkatan sebesar } \\
20 \% \text { per tahun. }\end{array}$ \\
\hline & $\begin{array}{l}\text { 2. Dengan mengikuti program } \\
\text { Sawala Loyalty akan memberikan } \\
\text { keuntungan sesuai dengan level } \\
\text { pelanggan. }\end{array}$ & $\begin{array}{l}\text { Tingkat keuntungan berbeda - beda } \\
\text { namun dari setiap level sama - sama } \\
\text { memiliki keuntungan berupa pemberian } \\
\text { voucher discount, penawaran harga } \\
\text { lebih hemat, penawaran special, } \\
\text { mendapat rincian belanja bulanan. } \\
\text { Semakin tinggi level, semakin tinggi } \\
\text { keuntungan yang didapatkan dan } \\
\text { semakin banyak juga program yang } \\
\text { ditawarkan. Program Sawala Loyalty ini } \\
\text { memberikan benefit yang dapat } \\
\text { diketahui melalui survey yang } \\
\text { dilakukan minimal terjadi peningkatan } \\
\text { sebesar } 20 \% \text {. }\end{array}$ \\
\hline
\end{tabular}

Sumber: Diolah penulis(2021)

\section{SIMPULAN DAN IMPLIKASI}

Berdasarkan hasil serangkaian penelitian yang telah dilakuka penulis, penulis berhasil menyusun startegi berupa usulan program yang didukung oleh SCA atau Sustainable Competitive Advantage pada
Usaha Sawala Space \& Cofe. Adapun stretegi yang diusulkan tersebut dengan berupa usulan program seperti program buy 2 get 1 masker,program potongan harga(discount) dan program Sawala Loyalty. Program tersebut didukung dengan analisis Internal perusahaan,analisis VRIO Analisis SCA, hingga analisis penerapan strategi. 


\section{ENTREPRENEUR}

\section{Jurnal Bisnis Manajemen Dan Kewirausahaan}

\section{Program Studi Manajemen Fakultas Ekonomika dan Bisnis Universitas Majalengka}

Published every January and July e-ISSN : (Proses), p-ISSN: 2723-1941

Available online http://ejournal.unma.ac.id/index.php/entrepreneur

Diketahui bahwa dalam analisis penerapan strategi Sawala Space \& Café harus memperhatikan proses bisnis yang terdiri atas input, proses, output, outcome,benefit dan impact serta juga harus memperhatikan komponen dan harus diterapkan sesuai dengan indikatornya.

Berdasarkan pembahasan diatas, penulis menyimpulkan sebagai berikut:

1. Retention rate Sawala Space \& Cofe sebesar $27,787 \%$. Nilai tersebut masih berada dibawah rata - rata industri ritel yaitu sebesar $36-44 \%$. Sementara itu penulis menggunakan metode SCA untuk meningkatkan retention rate dan menentukan strategi terpilih namun dalam hal ini diperlukan penelitian lebih lanjut untuk membuat retention rate meningkat melalui serangkaian metode yang lebih banyak dan lebih bervariasi.

2. Berdasarkan analisis VRIO, didapatkan bahwa kompetitif sementara perusahaan terdiri dari: kapasitas gedung, kapasitas kursi, router wi-fi, peralatan maka, nperalatan dapur, lemari pendingin, perpustakaan dan meeting room. Melalui serangkai pengolahan SCA, didapatkan bahwa SCA-nya adalah lokasi strategis, relasi, inkubator bisnis, website dan reputasi. Dari SCA tersebut selanjutnya di cari TOWS-nya lalu didapat peluang, ancaman, kekuatan dan kelemahan perusahaan. Dari analisis TOWS dilakukan usulan strategi perusahaan dimana akan melakukan pencocokan dengan SCA. Apabila SCA dan usulan tersebut memiliki kaitan lebih banyak diantara usulan lainnya makan dapat diterima dan dilakukan analisis input, proses, output, outcome, benefit dan impact.

3. Berdasarkan serangkaian analisis tersebut didapatkan beberapa usulan program yaitu:

a. Program buy 2 get 1 masker

b. Potongan harga(discount)

c. Program Sawala Loyalty

Dari ketiga program tersebut merupakan kesimpulan penulis untuk memperbaiki retention rate perusahaan khususnya dan perbaikan bisnis yang lebih baik pada umumnya. Maka dari itu diperlukanlah tindakan nyata agar usulan tersebut dapat membantu Sawala Space \& Cofe menjadi lebih baik lagi.

\section{DAFTAR PUSTAKA}

\section{Buku}

Barney, J. B., \& Hesterly, W. S. (2015).

Strategic Management and

Competitive

Advantage. Person/Prentice Hall.

Danang, Sunyoto. (2013). Metodologi

Penelitian Akuntansi. Bandung:

Refika Aditama

Farris, Paul W., et all. (2010). Marketing

Metrics: The Definitie Guide to

Measuring Marketing Performance

Second Edition. Philadelphia:

Wharton School

Kotler, P., \& Keller, K. L. (2009).

Manajemen Pemasaran (ke 13 ed., 


\section{ENTREPRENEUR}

\section{Jurnal Bisnis Manajemen Dan Kewirausahaan}

Program Studi Manajemen Fakultas Ekonomika dan Bisnis Universitas Majalengka Published every January and July e-ISSN : (Proses), p-ISSN: 2723-1941 Available online http://ejournal.unma.ac.id/index.php/entrepreneur

Vol. I). (B. Sabran, Trans.) Jakarta: Erlangga.

McMillan, J.H. and Schumacher, S. (2001). Research in Education. New York: Longman, Inc.

Nawawi, Hadari. (2003). Metode Penelitian Bidang Sosial. Yogyakarta: UGM Press.

Pusat Pembinaan dan Pengembangan Bahasa. (1998). Kamus Besar Bahasa Indonesia. Jakarta: Balai Pustaka

Riduwan. (2014). Metode dan Teknik Menyusun Proposal Penelitian. Bandung: Alfabta.

Sugiyono. (2016). Metode Penelitian Kuantitatif, Kualitatif dan R\&D.

Bandung: Alfabeta.

Ah-Keng Kau, Elizabeth Wan-Yiun Loh. (2006) The Effects of Service Recovery on

Consumer Satisfaction: a comparison between complainants and non- complainants. Vol.20, hlm. 101-111.

Badan Pusat Statistik. (2019). Statistik Kopi Indonesia. Jakarta: Badan Pusat Statistik

Barney, Jay B. and William S. Hesterly. (2015). Strategic Management and Competitive Advantage Concepts and Cases 15 th Edition. Pearson Education Limited, England.

Blattberg, Robert C. Gary Getz. Jacquelyn S. Thomas. (2001). Customer Equity: Building and Managing Relationships as
Valuable Assets. Massachusetts: Harvard Business Review Press.

Buttle, F. (2004). Customer Relationship Management: Concepts and Tools. Oxford: Elsevier.

Danang, Sunyoto. (2013). Metodologi Penelitian Akuntansi. Bandung: Refika Aditama

Farris, Paul W., et all. (2010). Marketing Metrics: The Definitie Guide to Measuring Marketing Performance Second Edition. Philadelphia: Wharton School

Kotler, Philip. 1997. Manajemen Pemasaran: Analisis, Perencanaan, Implementasi, dan Kontrol. Jakarta: Prehalindo.

Nawawi, Hadari. (2003). Metode Penelitian Bidang Sosial. Yogyakarta: UGM Press.

Pusat Pembinaan dan Pengembangan Bahasa. (1998). Kamus Besar Bahasa Indonesia. Jakarta: Balai Pustaka

Riduwan. (2014). Metode dan Teknik Menyusun Proposal Penelitian. Bandung: Alfabta.

Sugiyono. (2016). Metode Penelitian Kuantitatif, Kualitatif dan R\&D. Bandung: Alfabeta.

\section{Jurnal:}

Anderson, Eugene W. (1994). Cross-Category Variation in Customer Satisfaction and Retention. Marketing Letters 5:1, (1994): 19-30. Netherlands: Kluwer Academic Publishers. 


\section{ENTREPRENEUR \\ Jurnal Bisnis Manajemen Dan Kewirausahaan \\ Program Studi Manajemen Fakultas Ekonomika dan Bisnis Universitas Majalengka \\ Published every January and July e-ISSN : (Proses), p-ISSN: 2723-1941 \\ Available online http://ejournal.unma.ac.id/index.php/entrepreneur}

Anderson, Eugene W. Vikas Mittal. (2000).

Strengthening the Satisfaction-Profit Chain

First Published November 1, https://doi.org/10.1177/1094670500320 01

Darmawan, Didit. Samsul Arifin. Fajar Purwanto. (2020). Studi tentang Persepsi Nilai, Kepuasan dan Retensi Pelanggan Kapal Penyeberangan Ujung-Kamal. Jurnal Baruna Horizon Vol. 3, No. 1, Juni. https://jurnal.stiamak.ac.id.
Pfeifer, Phillip E. and Paul W. Farris. (2004). The Elasticity of Customer Value to Retention: The Duration of a Customer Relationship. First published: April 13. https://doi.org/10.1002/dir.20006

P. Jonathan, H. Saragih. 2017. Analisa Strategi Pemasaran Starbucks Menggunakan Analisis VRIO dan SWOT. National Conference on Business Management and Accounting 1 (1) vol: I issue: I. 